\title{
Iraq's Public Administrative Policies - Connections to Religion and the Views of the Islamic State
}

\author{
Cosmina loana Craciunescu* \\ Department of Public Policy Analysis, University of Babes-Bolyai, Romania
}

\begin{abstract}
For the Western world, the administrative policies are regarded as rules and regulations passed by the legislative bodies. These are the core aspects keeping the society strong, in order to fulfill some of the goals that the people pertaining to certain groups have in common. The purpose of the present article is to provide an understanding of the way the public administrative system of policies in Iraq functions, taking into account the teachings of the Holy Qur'an, the Islamic religion, and the influence of the Islamic State. The motivation behind the present topic is represented by the attempt of clarifying the fact that the Middle Eastern administrative system is based on the teachings of the Holy Book. Unlike the Western ways of the society, the Ummah (the Islamic community), is very influenced by the Qur'an, having a tendency to rely on the Word of Allah, seeking answers for their daily struggles.
\end{abstract}

Keywords: Public Administration; Quran; The Islamic State; Religion Methodology and Research Questions

The methodology employed for the present article is qualitative, as the data is collected and expressed in the form of words. It is used in order to gain an understanding of the underlying reasons, opinions and motivations, at the same time, providing insights into the problem of focus, helping at the development of the research. The method is the qualitative document analysis, as among the documents used were the Holy Qur'an, two short studies on the public administration of Iraq, along with copies of the documents used by the Islamic State that were published online.

Connected to the present article, the following questions were considered: What is the connection between the current system of public administration of Iraq, along with its policies, and the Holy Qur'an? To what extent is the Islamic State capable of influencing the system, and how does it work for the governance?

\section{Theory}

The public administration of Iraq is currently influenced by the presence of the Islamic State in the country. Along with their victory over the territories of Iraq and Syria, the terrorist group managed to bring changes into the system that eventually added to great social, political and economic disturbance. It is particularly important to bring upfront the main problem connected to the very existence of the Islamic State, being religion. Since the group is part of the Sunni branch of Islam, the largest of the main Islamic factions, one might take into account the fact that the Islamic State might believe that it is entitled to control the countries that are "subordinated" to their rule.

Moreover, the Islamic State members belong to the Salafi movement, being known as an ultra-conservative move that takes place under the auspices of Sunni Islam, advocating the return to the traditional laws of Islam.

\section{Main Research Focus}

The Islamic State's leadership structure knew a wave of shrinking, being marked by exclusiveness [1]. According to the available information, Abu Bakr al-Baghdadi knew a political accession back in 2010 , that eventually allowed him to maintain a personal advisor, along with two deputies, an eight-man cabinet, along with a military council of 13 men.
Moreover, al-Baghdadi brings a very powerful image of Islamic legitimacy, this being justified by his $\mathrm{Ph}$. D. degree in Islamic Studies that he obtained from the University of Baghdad. Because of his clerical experience, Baghdadi is regarded as being superior to Osama bin Laden or Zawahiri [1]. From the information that was presented above, one can come to the conclusion that the religious life is an extremely important topic for the Islamic community.

Relying on their values, the Islamic State strongly supports the religious movements, along with any kind of connection made to the superior beings. Because of their strong influence in Iraq, and due to the fact that they own territories and a large amount of resources, the terrorist group succeeded in taking over the society and make it play by their own rules. On the other hand, the Islamic State bases its beliefs on the Holy Qur'an, embracing the Wahhabi doctrine, which provides a set of strict rules and interpretations on the Islamic way of life. This movement is known to be a reform, being described as "austere, fundamentalist and puritanical", and also as "a deviant sectarian movement".

With regard to the Holy Qur'an, many links were discovered between the current system of public administration promoted by the Islamic State, and the way the Holy Book is encouraging government. One example is the chapter that describes the Romans (ar-Rum) as people who rejected God's revelations.

48 And do not obey the blasphemers and the hypocrites, and ignore their insults, and rely on God."--this excerpt from the Holy Qur'an could explain the attitude of the Islamic State toward the modern - Western governance. According to the extremist group's opinion, especially of those who abide by the Wahhabi doctrine, democracy represents a blasphemy in front of Allah.

*Corresponding author: Cosmina loana Craciunescu, Department of Public Policy Analysis, Romania, Tel: +40741091904; E-mail: cosmina@postmail.ro

Received April 26, 2017; Accepted May 11, 2017; Published May 15, 2017

Citation: Craciunescu Cl (2017) Iraq's Public Administrative Policies - Connections to Religion and the Views of the Islamic State. Review Pub Administration Manag 5: 209. doi:10.4172/2315-7844.1000209

Copyright: $\odot 2017$ Craciunescu $\mathrm{Cl}$. This is an open-access article distributed under the terms of the Creative Commons Attribution License, which permits unrestricted use, distribution, and reproduction in any medium, provided the original author and source are credited. 
In the passage named "The Unleashed", it seems that the reason for the actions that are undertaken by the Islamic State can be found: "By those unleashed in succession/ storming turbulently/ Scattering far and wide/ Separating decisively/ Delivering a message/ Excusing or warning". These, without a shadow of a doubt, reflect the views of the group that are related to the Last Day, in an attempt to find a logical explanation for their actions.

\section{The Islamic State's Public Administration}

Even though some light is starting to draw upon the nature of the administrative affairs of the Islamic State, there are still many issues that were left unanswered, as well as many gaps of information that need to be addressed.

The Islamic State embodies a system of diwans, which are known to be government departments, existing ever since the declaration of the Caliphate in June of 2014. The active personnel of the organization were eventually compelled to return to work within the public system under the threat of confiscation of their houses [2].

The body that is dealing with legal matters corresponding the Islamic State is named Diwan al-Qadaa wa al-Mazal, and Diwan alHisbah, which are bodies that deal with legal matters involving real estate, along with the enforcement of the Shariah law [2].

Among the documents that were found and eventually sent to analysis, there is information connected to the rebuilding of roads in order to ease the traffic, as well as an establishment of a maintenance workshop system for the sewage pertaining to the eastern quarter of the country.

In order to address the issue of food shortages, some decrees were passed such as inspection of shops in several regions of the country, for the purpose of confiscating goods and the distribution of them to the population.

It is particularly important to point out the fact that every single administrative document issued by the Islamic State starts with a religious reference to Allah. God calls the merciful (In the Name of Allah, The Compassionate, The Merciful). In this manner, the Islamic State's administration shows the fact that they are driven by the Holy Word of Allah, as they make efforts to guide the Ummah of Iraq on the "right path".

Another important thing is the fact that the Islamic State stamps all the documents with the main date starting from the point of the Declaration of the Caliphate [2]. An interesting connection can be made between this aspect and the fact that the modern world keeps track of time ever since the birth of Jesus Christ, the central figure of Christianity. The meaning that the Islamic State is trying to attach to their actions and way of government can be interpreted as a potential "rebirth" of the Islamic civilization, since the era of Muhammad.

Basically, under the rule of the Islamic State, every action that is undertaken, including several works that have to be done in the cities of Iraq and Syria, for the purpose of improving the life of the community, is backed by religious arguments. Also, every social problem that is encountered, (and it always has to do with people that broke the law), is made public and saved in the files of the administration. This constitutes not only the attempt, but also proves the efforts of the Islamic State to go back to the old, medieval laws, which included people that faced several trials, and were stoned in public.

\section{The Islamic State's Administrative Documents}

One of the most interesting documents that were found to be administrative in nature had connections to the Palmyra religious site, where a law was passed, as it forbade the movement of any of the historical artefacts found in the region. This law is particularly important, since the site dates back to the Mesopotamian era, being one of the most valuable cultural areas in the world. Moreover, besides the fact that protecting the historical sites was an expected move, one can draw a conclusion on the basis of the Islamic State's "value", as the presence of these artefacts made the group come to the conclusion that it is entitled to rule the area, as they consider themselves the "purest" people abiding by the Islamic religion. With this in mind, a reference can also be made to the destruction of many temples and historical sites by the same group. The intriguing aspect resides in the fact that the Islamic State exposes their will to "keep the old order" guiding themselves by the Qur'an, at the same time, destroying the most valuable cultural heritages of the world. A possible explanation for their gruesome acts can also be found in the Qur'an, where it states that Muslims are not allowed to worship any other deity besides Allah.

\section{Understanding the Rules of the Quran}

This extract from the Holy Qur'an illustrates the fact that a Muslim should believe in no other higher authority but Allah.

You worship only idols instead of God, and thus you invent a mere falsehood. Surely those that you worship instead of God do not have the power to provide for you; so seek all your provision from God, and worship him and be thankful to Him. To Him you are being brought back.

From this excerpt, in particular, one can come to the conclusion that the self-sufficiency of the Islamic State can be explained, due to the fact that it is stated that no other power may have a strong word when it comes to Iraq. The problem with the approach can easily be observed in their daily life, as the group brought more disorientation and chaos, instead of guiding the Iraqi society to a straight path. Another issue is represented by the fact that Iraq is falling behind in terms of socioeconomic stability, and the countries that were willing to intervene came to be regarded as intruders. On the other hand, the intervention of the Western states did not prove to be an appropriate move, as the history showed. Due to the long intervention and presence of the United States military in Iraq, the social and political divisions deepened in the area, instead of reaching a stable line, eventually leading to the disturbances that we all witness today.

\section{Governing by the Religious Law}

The provincial Sharia Committees are those responsible for the oversight of the activities that take place within the provincial Diwans, strictly on matters connected to religion. The committees are able to issue their own directives considered pertinent to specific problems to the required provinces. On the other hand, the Greater Diwans are subordinate to the highest council of the Islamic State. All these superior bodies that are related to the religious affairs responsible for answering to the Islamic State's Highest Sharia Council [3].

With regard to the Hijra Committee, which is tasked to provide financial support allocated to those who are willing to migrate to the Caliphate, it is important to understand the fact that the name is taken from the period of time when Muhammad migrated from Mecca to Medina. This time span is referred to in the Qur'an, as the "Hegira", or "Hijra". It seems that the name of the committee was chosen based on religious connections, in order to bring the people toward the view of a prosperous Caliphate, abiding by the Islamic State's propaganda [4].

With regard to the education department, the teachers are forced to 
Citation: Craciunescu CI (2017) Iraq's Public Administrative Policies - Connections to Religion and the Views of the Islamic State. Review Pub Administration Manag 5: 209. doi:10.4172/2315-7844.1000209

Page 3 of 3

carry out their work following the Holy Word, as the science materials are forbidden. The Diwan al-'Eftaa wa Al-Buhuth, which is the Islamic State's fatwa and research department [3], is a Diwan that surfaced since the declaration of the Caliphate. The Diwan is issuing books for re-education and repentance of teachers, and various justifications are found for the gruesome acts carried out by the Islamic State, among which the hostage-taking acts and the vicious killing of the Jordanian pilot, along with the beheading of American journalists can be found [5]

\section{Results and Discussion}

At the end of the present study, a clear picture is painted around the Islamic State's way of governing. The research showed that the Islamic State is very influenced by the Holy Qur'an, trying to implement and integrate the religious laws into the ones governing the day-to-day life of the Iraqi people. The analysis and interpretation of the documents were intended to bring to light the main problems surrounding the rules imposed by the organization, in an attempt to understand the mechanisms behind the actions taken at the level of government in Iraq, connecting everything to the views of the Islamic State [6].

\section{Conclusion}

It is difficult to understand the nature of the Islamic State's way of governing. However, one must take into account the fact that as long as a society will be led by religious means, it will know a long reign in a certain area. This is particularly because there is no greater power than the one generated by the deepest emotions of the people. Religion does not have to be seen as an exotic aspect of life, but rather as an expression of the identity pertaining to a group, or a society [7]. However, as history already proved, the religious arguments will not be everlasting, as they tend to stand in the way of development, according to the modern thinking.

\section{References}

1. Lister C (2014) Brookings Doha Center, Proling the Islamic State.

2. Zelin AY (2015) Jihadology, The Archivist: 26 Unseen Islamic State Administrative Documents: Overview, Translation \& Analysis.

3. Tamimi Al (2016) How the islamic state governs. The Journal of International Security Affairs.

4. Wood G (2015) The Atlantic, What ISIS Really Wants.

5. Tamimi Al (2015) Perspectives on terrorism, The Evolution in Islamic State Administration: The Documentary Evidence 9: 4.

6. Tamimi Al (2016) Governance in Islamic State Provinces beyond Iraq and Syria.

7. Zelin A (2014) The Atlantic, The Islamic State of Iraq and Syria: Consumer Protection Office. 